\title{
MORPHOLOGY OF IN VITRO EXPANDED HUMAN MUSCLE - DERIVED STEM CELLS
}

\author{
Lubos Danisovic ${ }^{\mathrm{a} *}$, Ivan Varga ${ }^{\mathrm{b}, \mathrm{c}}$, Stefan Polak ${ }^{\mathrm{b}}$, Marcela Ulicna $^{\mathrm{a}}$, Daniel Bohmer ${ }^{\mathrm{a}}$, \\ Jan Vojtassak ${ }^{\mathrm{a}}$
}

a Institute of Medical Biology and Genetics, Faculty of Medicine, Comenius University in Bratislava, Sasinkova 4, 81108 Bratislava, Slovak Republic

${ }^{b}$ Institute of Histology and Embryology, Faculty of Medicine, Comenius University in Bratislava, Sasinkova 4, 81108 Bratislava, Slovak Republic

c Institute of Histology and Embryology, Faculty of Medical Specialty Studies, Slovak Medical University, Limbova 12, 83303 Bratislava, Slovak Republic

e-mail:lubos.danisovic@fmed.uniba.sk

Received: October 16, 2008; Accepted: November 30, 2008

Key words: Muscle-derived stem cells/Morphological analysis/Phenotypical analysis

Background: Skeletal muscle contains populations of multipotent adult stem cells also referred to as muscle-derived stem cells.

Aim: The main goal of this study was to isolate and culture human adult stem cells from skeletal muscle and characterize them.

Methods: Muscle-derived stem cells were isolated from biopsy specimens of femoral muscle. The cells were cultured in Dulbecco's modified Eagle's minimal essential medium supplemented with 10\% fetal calf serum and gentamycin. When they reached confluence, they were sub-passaged up to the third passage. Cells from the last passage were prepared for TEM analysis. Production of $\alpha$-actin and desmin was confirmed by histochemistry. Moreover, the phenotypic characterization was performed.

Results: Primary isolated muscle-derived stem cells had a fibroblast-like shape. During subsequent passages they maintained this morphology. TEM analysis showed typical ultrastructural morphology of mesenchymal stem cells. They had large pale nuclei with a large amount of euchromatine. Nuclei were irregular with noticeable nucleoli. Dilated cisterns of rough endoplasmic reticulum were present in cytoplasm. In certain parts of the cytoplasm there were aggregates of granules of glycogen. The products of cells were actively secreted into the extracellular matrix. They expressed $\alpha$-actin and desmin. The results of phenotypic characterization showed that almost all analyzed cells were CD13, CD34, CD56 positive and CD45 negative. Moreover, they did not express anti-human fibroblast surface protein.

Conclusions: Muscle-derived stem cells exhibited typical characteristics typical for mesenchymal stem cells. After analysis of their differentiation potential they could be used in tissue engineering and regenerative medicine.

\section{INTRODUCTION}

Stem cells are characterised as undifferentiated cells which have been derived from embryonic, foetal and adult organisms ${ }^{1-3}$. These cells are unique in their potential to generate various types of tissues under proper conditions in vitro and in vivo ${ }^{4}$. Embryonic and foetal stem cells are considered pluripotent but their utilization is restricted by ethical considerations ${ }^{5}$. For this reason, multipotent adult stem cells are promising for tissue engineering and regenerative medicine.

Over the past few years, adult stem cells have been derived from various types of tissues including bone marrow, umbilical cord blood, adipose tissue, skin, periosteum, dental pulp, etc. ${ }^{6-11}$. Adult stem cells are adherent and have a fibroblast-like morphology when cultured in vitro. These cells are heterogeneous and express a variety of surface markers including CD29, CD44, CD90, CD105, STRO-1 and Sca-1. Moreover, they are negative for haematopoietic markers CD34, CD45 and for HLA Class II (ref. ${ }^{12,13}$ ).

Skeletal muscle contains populations of myogenic cells (satellite cells) which are capable of differentiation into myoblasts and a population of multipotent stem cells also referred as multipotent muscle-derived stem cells $^{14,15}$. Satellite cells express myogenic markers MyoD, Myf5, desmin and PAX-1, and haematopoietic marker CD34 (ref. ${ }^{16,17}$ ), while muscle-derived stem cells are predominantly positive for Sca-1, CD13, CD34 and CD56 (ref. ${ }^{18,19}$ ) and negative for CD45 (ref. ${ }^{20}$ ). Muscle-derived stem cells are usually isolated by the serial plating technique which is based on the different propensity of cells to adhere to cultivation substrate and lead into the purification of myogenic cells ${ }^{21}$.

The aim of this study was to isolate and culture in vitro human muscle-derived stem cells and do a morphological and phenotypical analysis of them. 


\section{MATERIAL AND METHODS}

\section{Isolation and cell culture}

Human muscle cells were obtained under sterile conditions from a biopsy specimen (sized $2 \times 5 \mathrm{~mm}$ ) of femoral muscle (male individual, 3-month-old). The sampling was indicated for a genetic examination and was performed in accordance with The Helsinki Declaration. The muscle was carefully rinsed with sterile phosphate buffered saline (PBS, Oxoid, UK) supplemented with gentamycin in final concentration of $200 \mu \mathrm{g} . \mathrm{ml}^{-1}$ (Lek, Slovenia). Then cut into small pieces and digested with $0.1 \%$ collagenase type I (Pan Biotech, Germany) for $60 \mathrm{~min}$. at $37^{\circ} \mathrm{C}$. The obtained suspension was centrifuged at $1000 \mathrm{rpm}$ for 10 min. The resultant supernatant was aspirated and sediment was resuspended in $10 \mathrm{ml}$ of $0.25 \%$ trypsin-EDTA solution (PAA, Austria) for $30 \mathrm{~min}$ at $37{ }^{\circ} \mathrm{C}$. The final suspension was filtered through $70 \mu \mathrm{m}$ pore-size cell strainer (BD Falcon, US) and centrifuged at $1000 \mathrm{rpm}$ for $5 \mathrm{~min}$. The supernatant was carefully removed and sediment was resuspended in Dulbecco's modified Eagle's minimal essential medium (DMEM, Pan Biotech, Germany) containing $10 \%$ foetal calf serum (FCS, PAA, Austria) and gentamycin in a final concentration of $80 \mu \mathrm{g} \cdot \mathrm{ml}^{-1}$. The suspension was plated on an uncoated Petri dish $(\varnothing 40$ $\mathrm{mm}$, Swiss) assigned as PP1 and paced in $\mathrm{CO}_{2}$ incubator $\left(37{ }^{\circ} \mathrm{C}, 5 \%\right.$ of $\mathrm{CO}_{2}$ in air) for $120 \mathrm{~min}$. After $2 \mathrm{~h}$, unattached cells floating in medium were collected and plated on other Petri dish assigned as PP2. The procedure was repeated after $24 \mathrm{~h}$ incubation and the last Petri dish was designated PP3. Cells from PP3 were cultured for 21 days to obtain a sufficient number of cells, and the culture medium was refreshed every $48 \mathrm{~h}$. When the cells reached confluence, they were trypsinized and subpassaged up to the $3^{\text {rd }}$ passage. Cells from last passage were prepared for histological and histochemical analysis according to standard protocols. The phenotypic characterization was done by flow cytometry.

\section{Phenotypical analysis}

Bone marrow and adipose tissue derived MSCs from the third passage were analyzed by direct and indirect immunofluorescence, according to protocols specific for each antibody. In each case, 10000 events were acquired and analyzed by a Coulter Epics ALTRA flow cytometer. The following anti-bodies were used for cell staining: antiCD34-FITC; anti-CD56-FITC; anti-human fibroblast surface protein (Sigma Aldrich, USA); anti-CD-13-PECy5; anti-CD45-PE-Cy5 (Dako Glostrup, Denmark); with a secondary FITC-conjugated donkey anti-mouse IgG antibody (Chemicon, USA).

\section{Morphological analysis}

The morphology of the in vitro expanded cells was repeatedly examined under inverted microscope Zeiss Axiovert 100 during cultivation.

Cells intended for immunohistochemical analysis were fixed with cold methanol for $1 \mathrm{~min}$. After that they were prepared for immunoflurescence staining against $\alpha$-actin

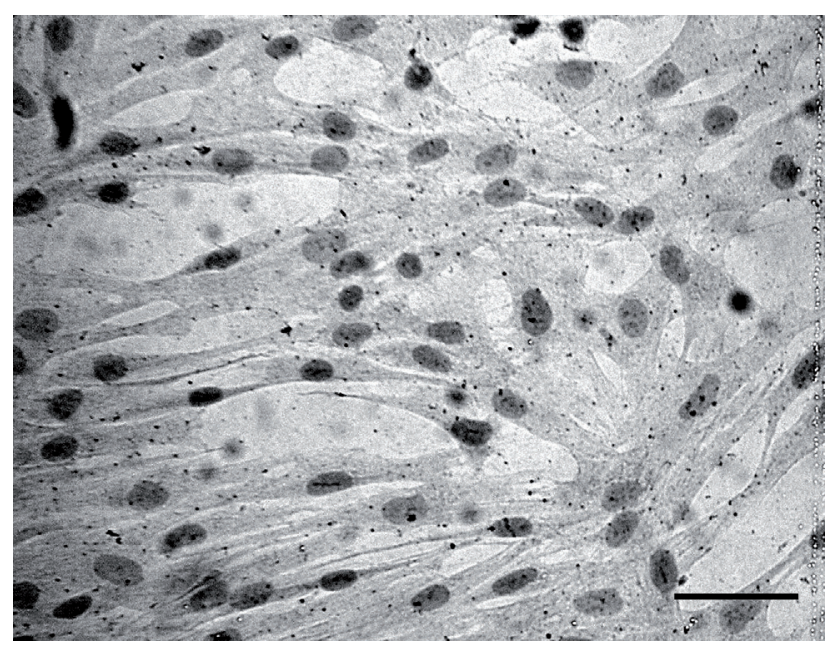

Fig. 1. Cell cultures of human muscle-derived stem cells. Scalebar $=100 \mu \mathrm{m}$.
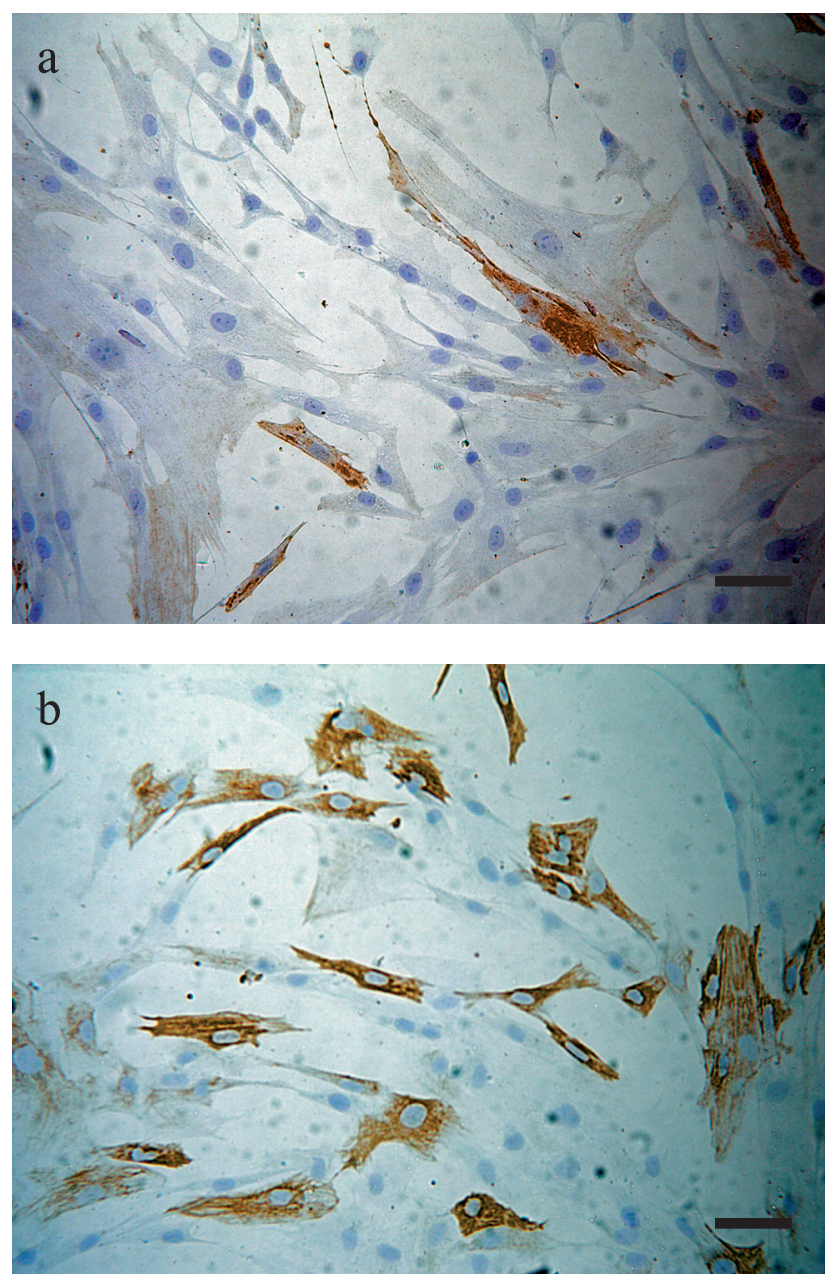

Fig. 2. Immunohistochemical staining for $\alpha$-actin (a) and desmin (b). Scalebar $=100 \mu \mathrm{m}$.

and desmin (Dako Glostrup, Denmark) according to standard protocol.

Cells set aside for transmission electron microscopy observation were fixed with $2.5 \%$ glutaraldehyde (SigmaAldrich, Germany) for $4 \mathrm{~h}$. After fixation, samples were 

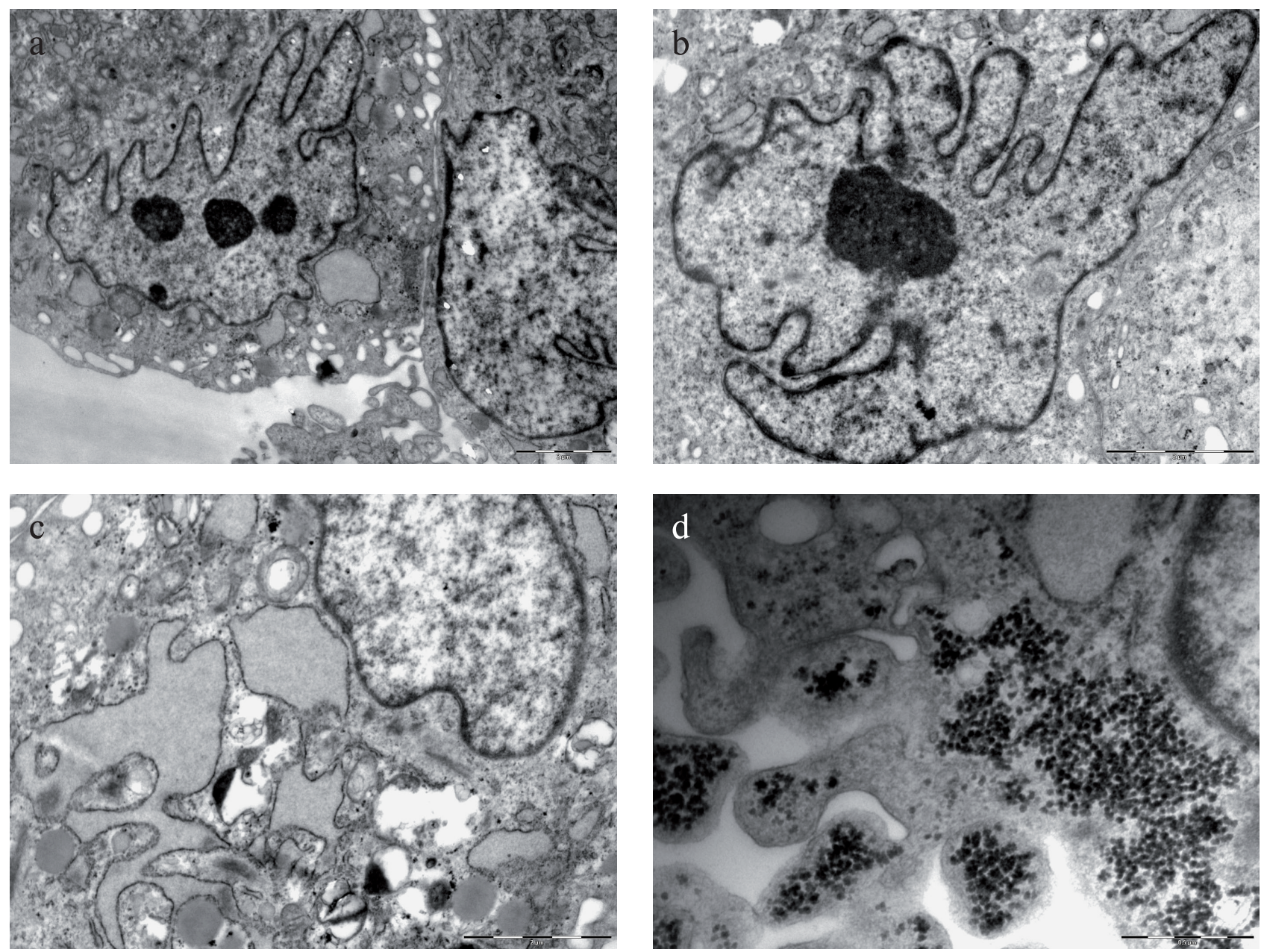

Fig. 3. TEM analysis of human muscle-derived stem cells

rinsed in PBS and postfixed in $2 \%$ osmium tetraoxide (Serva, Germany) for $2 \mathrm{~h}$, then rinsed in distilled water and dehydrated in a graduated series of ethanol. Subsequently, the samples were embedded in EPON and cut into semi-thin sections. Ultra-thin sections were mounted on 200 mesh copper grids, then double stained using uranyl acetate and lead citrate (Serva, Germany) and examined using a Philips Morgagni transmission electron microscope.

\section{RESULTS AND DISCUSSON}

In the present study we have performed morphological and phenotypical characterization of human musclederived stem cells. These cells were considered to be multipotent and so they are interesting for cell therapy $^{16,19,20}$. We used the generally accepted serial plating technique to obtain a population of stem cells ${ }^{21}$. Primary isolated muscle-derived stem cells had a fibroblast-like morphology (Fig. 1). During subsequent passages they maintained this morphology. Phenotypical analysis showed that almost all of the analyzed cells were CD13, CD34 and CD56 positive and, CD45 negative. This is in accord with other studies ${ }^{17,22,23}$. They did not express anti- human fibroblast surface protein. The immunohistochemical analysis showed expression of $\alpha$-actin and desmin (Fig. 2), which indicates their mesenchymal origin as well as their myogenic capacity ${ }^{24}$. TEM analysis showed typical ultrastructural morphology of mesenchymal stem cells (Fig. 3). They had large pale nuclei with a large amount of euchromatine. Nuclei were irregular with noticeable nucleoli. Dilated cisterns of rough endoplasmic reticulum were present in the cytoplasm. In certain parts of the cytoplasm there were aggregates of granules of glycogen. The products of cells were actively secreted into the extracellular matrix. In summary, muscle-derived stem cells exhibit characteristics typical for mesenchymal stem cells. After other analysis they could be used in tissue engineering and regenerative medicine.

\section{ACKNOWLEDGEMENTS}

This work was supported by grant VEGA No. 1/0397/08 


\section{REFERENCES}

1. Thomson JA, Itskovitz-Eldor J, Shapiro SS, Waknitz MA, Swiergiel JJ, Marshall VS, Jones JM. Embryonic stem cell lines derived from human blastocysts. Science 1998; 282:1145-7.

2. Kues WA, Petersen B, Mysegades W, Carnwath JW, Niemann H. Isolation of murine and porcine fetal stem cells from somatic tissue. Biol Reprod 2005; 72:1020-8.

3. Baksh D, Song L, Tuan RS. Adult mesenchymal stem cells: characterization, differentiation, and application in cell and gene therapy J Cell Mol Med 2004; 8:301-16.

4. Barry FP, Murphy JM. Mesenchymal stem cells: clinical applications and biological characterization. Int J Biochem Cell Biol 2004 36:568-84.

5. Henon PR. Human embryonic or adult stem cells: an overview on ethics and perspectives for tissue engineering. Adv Exp Med Biol 2003; 534:27-45

6. Caplan AI. Mesenchymal stem cells. J Orthop Res 1991; 9:64150 .

7. Watt SM, Contreras M. Stem cell medicine: umbilical cord blood and its stem cell potential. Semin Fetal Neonatal Med 2005 10:209-20.

8. Zuk PA, Zhu M, Mizuno H, Huang J, Futrell JW, Katz AJ, et al. Multilineage cells from human adipose tissue: implications for cellbased therapies. Tissue Eng 2001; 7:211-28.

9. Toma JG, McKenzie IA, Bagli D, Miller FD. Isolation and characterization of multipotent skin-derived precursors from human skin Stem Cells 2005; 23:727-37.

10. De Bari C, Dell ' Accio F, Luyten FP. Human periosteum-derived cells maintain phenotypic stability and chondrogenic potential throughout expansion regardless of donor age. Arthritis Rheum 2001; 44:85-95.

11. Gronthos S, Brahim J, Li W, Fisher LW, Cherman N, Boyde A, et al. Stem cell properties of human dental pulp stem cells. J Dent Res 2002; 81:531-5.

12. Pittenger MF, Mackay AM, Beck SC, Jaiswal RK, Douglas R, Mosca JD, et al. Multilineage potential of adult human mesenchymal stem cells. Science 1999; 284:143-7.
13. Gronthos S, Zannettino AC, Hay SJ, Shi S, Graves SE, Kortesidis A, Simmons PJ. Molecular and cellular characterisation of highly purified stromal stem cells derived from human bone marrow. J Cell Sci 2003; 116:1827-35.

14. Hawke TJ, Garry DJ. Myogenic satellite cells: physiology to molecular biology. J Appl Physiol 2001; 91:534-51.

15. Seale P, Rudnicki MA. A new look at the origin, function, and "stem-cell" status of muscle satellite cells. Dev Biol 2000; 218:11524 .

16. Asakura A, Komaki M, Rudnicki M. Muscle satellite cells are multipotential stem cells that exhibit myogenic, osteogenic, and adipogenic differentiation. Differentiation 2001; 68: 245-53.

17. Beauchamp JR, Heslo L, Yu DS, Tajbakhsh S, Kelly RG, Wernig A, et al. Expression of CD34 and Myf5 defines the majority of quiescent adult skeletal muscle satellite cells. J Cell Biol 2000; 151:1221-34.

18. Asakura A, Seale P, Girgis-Gabardo A, Rudnicki MA. Myogenic specification of side population cells in skeletal muscle. J Cell Biol 2002; 159:123-34.

19. Cao B, Huard J. Muscle-derived stem cells. Cell Cycle 2004; 3:104

20. Qu-Petersen Z, Deasy B, Jankowski R, Ikezawa M, Cummins J, Pruchnic R, et al. Identification of a novel population of muscle stem cells in mice: potential for muscle regeneration. J Cell Biol 2002; 157:851-64.

21. Machida, S, Spangenburg EE, Booth FW. Primary rat muscle progenitor cells have decreased proliferation and myotube formation during passages. Cell Prolif 2004; 37:267-77.

22. Young HE, Steele TA, Bray RA, Hudson J, Floyd JA, Hawkins K, et al. Human reserve pluripotent mesenchymal stem cells are present in the connective tissues of skeletal muscle and dermis derived from fetal, adult, and geriatric donors. Anat Rec 2001; 264:51-62.

23. Sinanan AC, Hunt NP, Lewis MP. Human adult craniofacial muscle-derived cells: neural-cell adhesion-molecule (NCAM; CD56)-expressing cells appear to contain multipotential stem cells. Biotechnol Appl Biochem 2004; 40:25-34.

24. Alessandri G, Pagano S, Bez A, Benetti A, Pozzi S, Iannolo G, et al. Isolation and culture of human muscle-derived stem cells able to differentiate into myogenic and neurogenic cell lineages. Lancet 2004; 364:1872-83 